\title{
Bruce Merrifield centennial: pioneer of chemical synthesis on solid matrix
}

\author{
Istvan Hargittai ${ }^{1}$
}

Accepted: 11 August 2021 / Published online: 27 August 2021

(c) The Author(s) 2021

\begin{abstract}
Bruce Merrifield (1921-2006) was an American biochemist who, at the Rockefeller Institute, invented a highly efficient technique for producing peptides and proteins in the early 1960s. He was awarded the Nobel Prize in Chemistry in 1984. We remember this highly original, low-profile contributor to chemistry on the occasion of the one hundredth anniversary of his birth.
\end{abstract}

Keywords Bruce Merrifield · Synthesis on solid matrix · Max S. Dunn · Rockefeller University · Wayne Woolley · Enzyme ribonuclease $\cdot$ Max Bergmann

The parents of Robert Bruce Merrified (1921-2006, Fig. 1) [1] grew up on farms in Texas, and when they were married, they moved to Fort Worth, where Merrifield was born [1]. The father, George E. Merrifield, served in World War I, graduated from a business school, and went into sales. He combined being a furniture salesman and an interior decorator. The family moved to California in 1923 and was hit by the Great Depression there when Bruce had hardly started school. The Great Depression impacted him for his entire life: He never tolerated waste and never bought anything on credit. He graduated from high school in 1939. He decided to become a researcher in chemistry while being a student at the University of California at Los Angeles, under the mentorship of Max S. Dunn (1895-1976). Max Dunn (Fig. 2) was one of the original founding faculties of the chemistry department at UCLA. His primary interest was in nucleic acids. Merrifield applied Dunn's methods of microbiological methods in his studies of pyrimidines for his doctorate.

As soon as he received his PhD degree in 1949, Merrifield married Elizabeth Furlong, and they left for New York where he began his lifelong employment at the Rockefeller Institute for Medical Research. It transformed into the Rockefeller University from 1965 . The Rockefeller Institute, then, University,

Istvan Hargittai

stuceditor@gmail.com

http://istvan.hargittai.com

1 Budapest University of Technology and Economics, Budapest 1521, Hungary is a world-renowned research institution and graduate school. Initially, it was organized more like the leading European institutions of higher education. The professors had research associates who for years worked for the professor before becoming independent. This changed later, and the Rockefeller University became similar to the American system in which the young, tenure-track assistant professors become heads of their independent laboratories right away. Merrifield benefitted from the old system, and for years, he worked for the outstanding D. Wayne Woolley (1914-1966).

Wayne Woolley (Fig. 3) was an American biochemist born in Canada. He completed high school at age 13 and graduated from the University of Alberta at age 19. He earned his $\mathrm{PhD}$ degree in 1939 in the Department of Agricultural Chemistry at the University of Wisconsin. Woolley spent his entire career at the Rockefeller Institute. He studied vitamin deficiency and was a pioneer in investigating the role of serotonin in brain chemistry. He was nominated for the Nobel Prize several times between 1939 and 1950. Woolley had type 1 diabetes from childhood, and by his midtwenties, he became completely blind. Nonetheless, he carried on his research with the help of a technician as if he had no impediment. Over the years, Woolley had outstanding researchers for assistants and Merrifield was one of them.

Merrifield had already been working for Woolley for a few years when, at one point, in 1959, he told Woolley about an idea of his, viz., building up peptides using a solid anchor. Among Merrifield's tasks, he synthesized peptides, and it was a labor and time-consuming exercise. 


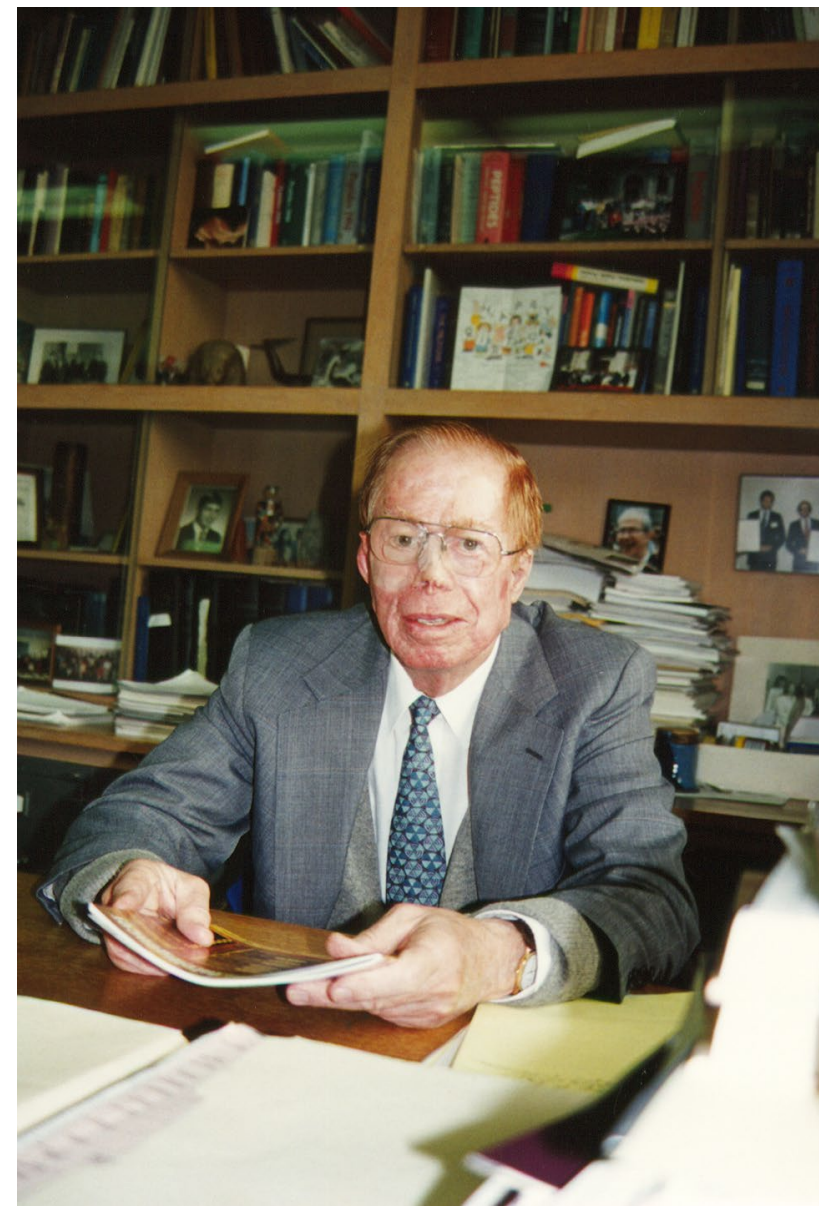

Fig. 1 Bruce Merrifield at his desk (1996) Rockefeller University (photograph by Istvan Hargittai)

This also served as a stimulus to creatively thinking about more efficient possibilities. His idea was to start the synthesis of a peptide attaching the first amino acid to a solid support that was insoluble in all the solvents used in the course of the synthesis. Then, it would be possible to add the next amino acid and the next and so on. After each reaction, it would be possible to filter and wash, and the peptide would stay attached to the support. When the needed sequence would be assembled, the bond to the support could be broken, and the peptide could be purified and crystallized-but this would be done only at the end rather than after each step as in a conventional procedure. This was the idea, which sounded simple, but the practical realization was a different matter. Woolley could, or might not, judge worthy of this idea to work on. Woolley did not react at once, but the next day, he told Merrifield to go ahead. This was a watershed decision, because Merrifield then did not produce new results and new publications for the next 3 years; he fully devoted his activities to turning his idea into a practical solution.
Had Merrifield been at that time an independent investigator, he could not have afforded to stay without results and publications for 3 years. Merrifield was patient, and it was more important that Woolley was patient, and so was the Institute- this was a tremendous advantage of the old system of how the Institute operated. When Merrifield was ready, he wrote up his manuscript, and Woolley told him to go ahead and publish it as its sole author [2]. This was another decisive difference-Woolley was well-known, whereas Merrifield was unknown, and had this report been a joint publication, it would have added to Woolley's fame and Merrifield's contribution could have been considered marginal. In this initial article, Merrifield described his new method on the example of the production of a tetrapeptide.

The Merrifields had six children, and when they no longer needed close parental attention, Elizabeth Merrifield joined him in working in the laboratory. Merrifield's group was always very small; he usually worked with one or two associates-doctoral student and post-doc — and a few technicians. His pupils became noted researchers themselves. Merrifield's innovation revolutionized the research of peptides and proteins. His goal was not merely to synthesize them, but to investigate well-defined biological questions. When his Nobel Prize was announced in 1984, the motivation read: "for his development of methodology for chemical synthesis on a solid matrix." The more detailed announcement mentioned in particular the synthesis of the enzyme ribonuclease, a protein consisting of a chain of 124 amino acids. Merrifield called it a "Rockefeller enzyme," because it was connected with the institution on several levels. The activity of this enzyme was discovered by René Dubos at the Rockefeller. It was isolated and crystallized by Moses Kunitz also there. Then, Alexander Rothen determined its molecular weight, and Stanford Moore and William Stein determined the sequence of its amino acids, also at the Rockefeller. Moore and Stein used their automated analyzer for its sequencing. They were awarded the 1972 Nobel Prize in Chemistry and the motivation read: "for their contribution to the understanding of the connection between chemical structure and catalytic activity of the active centre of the ribonuclease molecule."

Merrifield liked to emphasize that his work on peptides and proteins built on strong traditions at the Rockefeller. Max Bergmann (1886-1944) was the foremost peptide chemist in the world for quite some time. He was a former student of Emil Fischer in Germany and came to America as a GermanJewish refugee following the Nazi takeover. Bergmann assembled an excellent group of people, and Moore and Stein were among them, and others, such as Emil Smith, Klaus Hofmann, Carl Niemann, Conrad Frankel-Conrat, Mark Stahmann, and Paul Zamecnik. Merrifield inherited Max Bergmann's old office.

I briefly mention some of Merrifield's and his group's other research that also developed from his peptide work. 


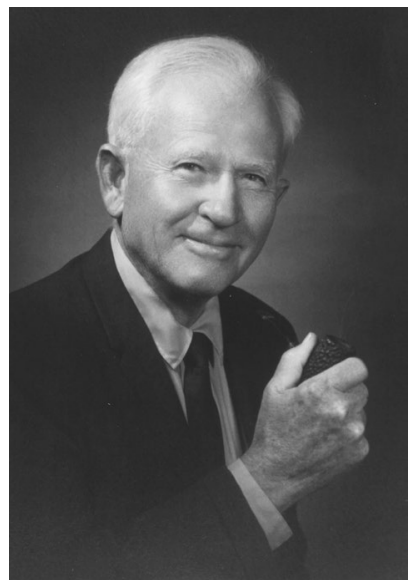

Fig. 2 Max Dunn around 1950 (courtesy of the late Bruce Merrifield)

They worked on a group of peptide antibiotics, linear peptides, quite active that had some effect on malaria parasites, tuberculosis bacilli, and other bacteria. Having in mind the resistance to antibiotics, particularly in hospitals, to produce major antibiotics had proved to be useless. However, producing new compounds that work by a different mechanism appeared to be important. The peptides they worked with, the cecropins, came from the giant cecropia silk moth. They were discovered in Sweden, and a cooperation with a Swedish laboratory proved to be most fruitful. Merrifield's group synthesized many such peptides and made the longer precursor protein. Merrifield became concerned about whether or not these peptides worked by some kind of a receptor, like a hormone does. They produced the all-D-peptide from D-amino acids, which is the mirror image of the natural all-L-version. Because it contains unnatural amino acids, hence its resistance to enzymes: The normal enzymes do not work on a D-amino acid. It turned out to be fully active, however, in a whole group of test organisms. Merrifield thought that the resulting peptides and proteins could be developed into a useful special purpose antibiotic, working by a different mechanism than penicillin and other well-known antibiotics. Alas, there was little interest in pursuing such a development, because the big companies did not see it as a major product. Merrifield regretted this very much, because tuberculosis may be coming back, and the normal antibiotics that had been useful in the past would not be effective in many cases.

During our long conversation on May 8, 1996, there was a question on my mind, but I felt awkward to ask Merrifield about it. His face showed noticeable marks of plastic surgeries. When I finally asked him about this, he felt comfortable to respond and his answer ended with a friendly advice: "When I was a teenager, I had an infection on my leg and I

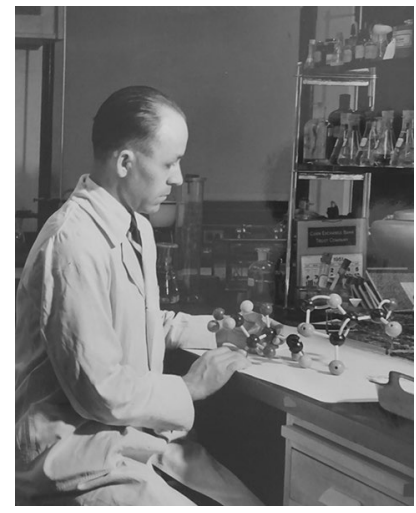

Fig. 3 Wayne Woolley in 1951 (courtesy of the late Bruce Merrifield)

went to a dermatologist with a brand new X-ray machine. He cured the leg but then he said, you have some acne on your face, why don't I cure that too? So he gave me X-ray treatment for that. It was fairly early in X-ray treatment, and the doses were very large. Then about 15 years later, tumors began to show up, and they have kept growing, and I have two or three a year that have to be removed. Don't ever let your kids have X-ray treatment unless it's absolutely critical" [3].

Bruce Merrifield was one of those few Nobel laureates who do not let the limelight change their lives. There was no doubt that he deserved this highest of distinctions, but he stayed what he had always been, a hard working researcher, hardly interested in anything outside his laboratory. He compared the Nobel Prize to lottery, because there are so many highly deserving people, so he could not fathom how the Nobel committees can weigh everything when they come to their decisions. He thought about this, because there was an additional reason that humbles the many scientists who received the Nobel Prize at the Rockefeller. Oswald Avery of the Institute, who (with his two junior associates) discovered that DNA was the substance of heredity-rather than proteins as it used to be believed-was never awarded a Nobel Prize. It was a major discovery, and its omission from the Nobel roster has become an embarrassment to the institution of the Nobel Prize [4]. The significance of work and discovery of Bruce Merrifield has not faded during the past decades. His scientific achievements and his unpretentious demeanor continue to encourage and inspire well-established scientists and budding researchers alike.

Funding Open access funding provided by Budapest University of Technology and Economics. 


\section{Declarations}

Conflict of interest The author declares no competing interests.

Open Access This article is licensed under a Creative Commons Attribution 4.0 International License, which permits use, sharing, adaptation, distribution and reproduction in any medium or format, as long as you give appropriate credit to the original author(s) and the source, provide a link to the Creative Commons licence, and indicate if changes were made. The images or other third party material in this article are included in the article's Creative Commons licence, unless indicated otherwise in a credit line to the material. If material is not included in the article's Creative Commons licence and your intended use is not permitted by statutory regulation or exceeds the permitted use, you will need to obtain permission directly from the copyright holder. To view a copy of this licence, visit http://creativecommons.org/licenses/by/4.0/.

\section{References}

1. Hargittai I (2003) Candid science III: more conversations with famous chemists (edited by M. Hargittai, London: Imperial College Press), Chapter 15, "Bruce Merrifield," pp 206-219

2. Merrifield RB (1963) Solid state peptide synthesis. I. Synthesis of a tetrapeptide. J Am Chem Soc 85:2149-2154

3. Hargittai I (2003) Candid science III: more conversations with famous chemists (edited by M. Hargittai, London: Imperial College Press), Chapter 15, "Bruce Merrifield," pp 206-219; actual quote, $\mathrm{p} 217$

4. Hargittai I (2002-2003) The road to Stockholm: Nobel Prizes, science, and scientists. Oxford University Press, Oxford, UK

Publisher's Note Springer Nature remains neutral with regard to jurisdictional claims in published maps and institutional affiliations. 